\title{
SOCIAL ENTREPRENEURSHIP AS A FORM OF SOCIAL RESPONSIBILITY IN BULGARIA
}

Social entrepreneurship is becoming a popular form of social responsibility and a way to solve a variety of urgent social problems. In order for a society to boost social entrepreneurship it needs a specific environment where such ideas can emerge and develop into an active business activity. This paper aims to provide a comprehensive literature review of the terms social responsibility and social entrepreneurship and to examine the current social entrepreneurship activities in Bulgaria. The analysis highlights the importance of social entrepreneurial ideas for improving the business climate in the country. A number of case studies are discussed to provide evidence of particular entrepreneurial activities which have successfully solved a number of social problems.

Key words: corporate social responsibility, social entrepreneurship, social responsibility

\section{Introduction}

There are a number of people and organizations contributing to the rise of social entrepreneurship. Today, the field has expanded to include the entire ecosystem involved with the promotion, support, and network of those involved with an endeavor designed to make the world a cleaner, more-equitable, healthier, and better-educated place. Another aspect of the social entrepreneurial movement is to approach social change with business rigor and analytical tools. Social entrepreneurship is an innovative form of business, which successfully combines social aims and commercial practice. Social entrepreneurship has emerged as a response to chronic social problems: unemployment, poverty, community fragmentation etc. Social entrepreneurship works where the government cannot work (due to the lack of funding), and the business does

Daniela Ilieva-Koleva, PhD, VUZF University / University of Sheffield International Faculty, Sofia, Bulgaria, e-mail: dkoleva@city.academic.gr

* Julia Dobreva, PhD, VUZF University / University of Sheffield International Faculty, Sofia, Bulgaria, e-mail: jdobreva@cit.academic.gr 
not want to (because of low profitability). ${ }^{1}$ The role of social entrepreneurship is to find a flexible and quick problem solving method. Every entrepreneurship is to a certain extent social entrepreneurship, and social entrepreneurship has as a goal to show the public sector how to be more effective and efficient. In most cases social entrepreneurship is about the resourcefulness and the intelligence of the social entrepreneurs to do something good or something needed by society.

The social agenda of the European Commission aims at raising living standards and improving living and working conditions, strengthening social cohesion and combating exclusion, promoting equal opportunities, and safeguarding sustainability. Currently Bulgaria is trying to find a solution to the different problems that it is facing such as: unemployment, aging population, changes of economic gender roles, and environmental problems. Bulgaria is among the poorest of the EU Member States and needs to appropriate policies to bring the country closer to the EU levels. Over the last two decades Bulgaria has undergone difficult transformations as part of its transition to market economy and democratic political system. The transitional period in the country has been accompanied by a sharp economic decline, increased poverty and unemployment, and a high level of corruption. In its effort to come closer to the economic levels of the EU Countries, Bulgaria will have to invest more in social development and try to solve its own specific social problems. Currently, the low level of public spending in health, education and social protection is not conductive to social development. In addition, Bulgaria will have to address specific issues such as combating corruption and introducing reforms of the justice system and of public administration, in order to ensure proper enforcement of the law2.

This colorful palette of social problems should make the country emphasize on and search for solutions based on social entrepreneurial ideas. According to the Economic and Social Council (ESC), social enterprises in Bulgaria should be encouraged to develop as a business model, not only within the so-called third sector through civil associations and foundations, but also in the private sector through regular business initiatives. It is necessary to discover and promote best practices and positive models achieved in Bulgaria, as well as to create conditions for the spread of good examples through the creation of national and international networks for the exchange of knowledge and experience.

This paper aims to provide a comprehensive literature review of the terms social responsibility and social entrepreneurship and to examine the current social entrepreneurship activities in Bulgaria. The analysis highlights the

Kostetska, I., Berezyak, I. (2014): "Social Entrepreneurship as an Innovative Solution Mechanism of Social Problems of Society", Management Theory and Studies for Rural Business and Infrastructure Development, Vol. 36, No. 3

2 Dulevski, L. (2013): Analysis on "the social enterprise and social entrepreneurship", Republic of Bulgaria, Economic and Social Council, http://www.esc.bg/ (03.02.2015). 
importance of social entrepreneurial ideas for improving the business climate in the country through several case studies of particular entrepreneurial activities, which have successfully solved a number of social problems.

\section{Social entrepreneurship}

Definitions of social entrepreneurship focus on the operating sector and/ or the processes and resources used by social entrepreneurs. These include identifying the manner in which the social enterprise is established as well as the primary activities undertaken by the social entrepreneur. ${ }^{3}$.

Gregory Dees, widely considered to be the "father" of the field of social entrepreneurship, in an unpublished paper written in 1998, claimed that social entrepreneurs play the role of change agents in the social sector by:

- Adopting a mission to create and sustain social value (not just private value);

- Recognizing and relentlessly pursuing new opportunities to serve that mission;

- Engaging in the process of continuous innovation, adaptation, and learning;

- Acting boldly without being limited by resources currently in hand;

- Exhibiting a heightened sense of accountability to the constituencies served and for the outcomes created. ${ }^{4}$

In defining social entrepreneurship this way, Dees helps the understanding of the major characteristics of business entrepreneurship that apply, the characteristics that make social entrepreneurship unique, and how the two are blended.

For the purpose of this paper the authors will only discuss social entrepreneurship definitions after 2006 as a more modern understanding of the concept is needed. According to Tracey and Jarvis "the notion of trading for a social purpose is at the core of social entrepreneurship, requiring that social entrepreneurs identify and exploit market opportunities, and assemble the necessary resources, in order to develop products and/or services that allow them to generate "entrepreneurial profit" for a given social project." ${ }^{5}$ Yunus defines it

3 Zahra, S. E., Gedajlovic, E., Neubaum, D. O., and Shulman, J. M. (2009): "A Typology of Social Entrepreneurs: Motives, Search Processes and Ethical Challenges". Journal of Business Venturing, 24(5), 519-532.

4 Lyons, T. S. (2013): "The Role of Social Entrepreneurship in Sustainable Business", http://www.triplepundit.com/, (http://www.triplepundit.com/2013/09/role-socialentrepreneurship-sustainable-business/) (03.02.2015)

5 Tracey, P., Phillips, N., and Jarvis, O. (2007): "Bridging institutional entrepreneurship and the creation of new organizational forms: A multilevel model”, Organization Science. 
by claiming that "any innovative initiative to help people may be described as social entrepreneurship. The initiative may be economic or non-economic, for-profit or not-for- profit." Zahra et.al. claim that "social entrepreneurship encompasses the activities and processes undertaken to discover, define, and exploit opportunities in order to enhance social wealth by creating new ventures or managing existing organizations in an innovative manner."

Masseti introduces the Social Entrepreneur Matrix $(\mathrm{SEM})^{8}$. Based on whether a business has a more market or socially driven mission and whether or not it requires profit, the SEM combines those factors that most clearly differentiate social entrepreneurism from traditional entrepreneurism. Martin and Osberg define social entrepreneurship as having the following three components: (1) identifying a stable but inherently unjust equilibrium that causes the exclusion, marginalization, or suffering of a segment of humanity that lacks the financial means or political clout to achieve any transformative benefit on its own; (2) identifying an opportunity in this unjust equilibrium, developing a social value proposition, and bringing to bear inspiration, creativity, direct action, courage, and fortitude, thereby challenging the stable state's hegemony; and (3) forging a new, stable equilibrium that releases trapped potential or alleviates the suffering of the targeted group, and through imitation and the creation of a stable ecosystem around the new equilibrium ensuring a better future for the targeted group and even society at large?

Hockerts claims that "social purpose business ventures are hybrid enterprises, straddling the boundary between the for-profit business world and social mission-driven public and nonprofit organizations." 10 This is the definition supported mostly by the authors of this paper as it reflects to a high extent the current social and economic environment in Bulgaria.

Traditional "for profit" and social entrepreneurs would do well to learn from each other. There are forums where all kinds of entrepreneurs can gather to share experiences and knowledge (a good example is IESE's annual Doing Good and Doing Well conference, the largest student- run event on responsible business and sustainability in Europe). These conferences and initiatives gather

Yunus, M. (2008): Creating a World without Poverty: Social Business and the Future of Capitalism. New York: Public Affairs Books.

7 Zahra, S. E., Gedajlovic, E., Neubaum, D. O., and Shulman, J. M. (2009): “A Typology of Social Entrepreneurs: Motives, Search Processes and Ethical Challenges". Journal of Business Venturing, 24(5), 519-532.

$8 \quad$ Masseti, B. L. (2008): “The social entrepreneurship matrix as a "tipping point” for economic change”, E:CO, 10(3), 1-8.

9 Martin, R. J., \& Osberg, S. (2007): "Social entrepreneurship: The case for a definition", Stanford Social Innovation Review,Spring, 29-39.

$10 \quad$ Hockerts, K. (2006): "Entrepreneurial opportunity in social purpose business ventures. In J. Mair, J. Robinson, \& K. Hockerts (Eds.)”, Social entrepreneurship. Basingstoke, UK: Palgrave Macmillan. 
experts from all sectors, allowing attendees to learn best practices to achieve sustainability. Vaccaro makes a suggestion of what traditional business can take from social entrepreneurs ${ }^{11}$ :

- High aims - high motivation: Social entrepreneurs are primarily looking to solve big problems in society, such as poverty, health, education, equal opportunities, etc. This encourages them to set high objectives and makes them more motivated (and thus the rest of their teams), knowing that they are working for an important cause.

- Markets are the means, not the goal: When starting a social venture, entrepreneurs see the problem first and then use the markets as a way to solve it, and not the other way around.

- People at the center: This is perhaps the main lesson every entrepreneur and manager should apply to their companies. When you work in a social enterprise you discover that people and their needs are at the center of organizational attention. This means internal and commercial operations are carried out with the intention to improve lives: not only the lives of customers, but employees, communities and other relevant stakeholders as well. This might not be new, but it is the key to making any company sustainable through the years.

- Financial sustainability: Profits are important for social entrepreneurs, but only in so far as they are an indicator of a financial sustainability, which in turn guarantees the achievement of the social mission. Every company has to be financially sustainable but profit concerns must not divert the social objectives of the organization. ${ }^{12}$

In the Bulgarian legislation there is no legal definition of social enterprise, nor are there any rules that regulate their status, form and activities. A Bulgarian legal act where the term "social enterprise" is used still does not exist. ${ }^{13}$

The existing forms of social entrepreneurship in Bulgaria for the moment are non-profit organizations which perform profit activities and use that profit for financing of the social mission of the organization. Another model is a non-profit organization which provides employment of people with disabilities or provides training services (for, example trainings or development of labor abilities). The third popular model is non-profit organizations engaged with social assistance. The forth form of social entrepreneurship in Bulgaria is the cooperative. Historically it has had the longest practical application, mainly in the period after World War II until 1990, although it

Vaccaro A. (2015): “4 Things We Can Learn From Social Entrepreneurs”, Forbes.

12 http://www.forbes.com/sites/iese/2015/01/28/4-things-we-can-learn-from-socialentrepreneurs/ (03.02.2015)

13 National Report on Social Economy Sector in Bulgaria, www.southeast- europe.net/ document.cmt?id=191 (03.02.2015) 
is rarely considered social entrepreneurship per se. In the survey conveyed by The South East Europe Transnational Cooperation Programme, 80\% of the Bulgarian social enterprises note the lack of governmental policy as a major obstacle to social entrepreneurship. Social enterprises in Bulgaria operate in different sectors. They are most frequently involved in:

- providing social services;

- providing employment for people with disabilities;

- mediation in finding a job for unemployed persons;

- providing healthcare services;

- activities related to education and others.

The provision of training and educational services is among the key sectors for social enterprises in Bulgaria.

\section{Social responsibility}

The European Commission puts forward a new definition of CSR as "the responsibility of enterprises for their impacts on society". Respect for applicable legislation and for collective agreements between social partners is a prerequisite for meeting that responsibility. To fully meet their corporate social responsibility, enterprises should have in place a process to integrate social, environmental, ethical, human rights and consumer concerns into their business operations with the aim of:

- maximizing the creation of shared value for their owners/shareholders and for their other stakeholders and society at large;

- identifying, preventing and mitigating their possible adverse impacts.

To maximize the creation of shared value, enterprises are encouraged to adopt a long-term, strategic approach to CSR, and to explore the opportunities for developing innovative products, services and business models that contribute to societal wellbeing and lead to higher quality and more productive jobs. To identify, prevent and mitigate their possible adverse impacts, large enterprises, and enterprises at particular risk of having such impacts, are encouraged to carry out risk-based due diligence, including through their supply chains. ${ }^{14}$

Corporate social responsibility is applicable to all enterprises. This communication is adopted together with a complementary but distinct Social Business Initiative $(\mathrm{SBI})^{15}$ which supports a specific kind of enterprise, namely those whose primary purpose is explicitly social and/or environmental. These enterprises reinvest profits

14 Communication from the Commission to the European Parliament, the Council, the European Economic and Social Committee of the Regions

15 http://ec.europa.eu/internal_market/social_business/docs/COM2011_682_en.pdf $(03.02 .2015)$ 
for that purpose and their internal organization reflects the societal objectives. The SBI deals with the ecosystem required for social business and social innovation to flourish and contribute to the European social market economy.

In the Bulgarian legal doctrine, as well as in most other European legal doctrines, there are two views regarding what should be the focus in defining the criteria to be met by the social enterprise - the legal form of the entity, giving it an explicit legal form and regulatory framework - or the behavior of the entity. The draft definitions indicated below show that the Bulgarian framework (so far only strategic) favors not so much the legal form, which will organize the social enterprise as a subject of the law, but rather its objectives and how it aims to pursue them. It is important that the activities of the social enterprise should be geared towards the provision of goods or services to persons with disabilities, the involvement of these actors in the production and provision of goods or services so as to achieve a positive social impact on society.

According to the National Report on Social Economy Sector in Bulgaria ${ }^{16}$, the following definitions apply to social enterprise:

- cooperatives, businesses and organizations duly registered under national law, whose business aims at social and humanitarian effects and which reinvest their profits for social causes;

- a business with leading social objectives, whose surplus is reinvested back into the business or in the community;

- a business that combines market opportunities with social causes, so that the main priority are the people and their needs.

Also, the report defines "social entrepreneur" as a person who mobilizes resources and uses opportunities to meet existing needs to help disadvantaged people. In this process s/he may use "compass for social enterprise" - a method to identify the affiliation of a legal entity to the social economy.

\section{Social entrepreneurship cases in Bulgaria}

\subsection{The National Alliance for Social Responsibility ${ }^{17}$}

The National Alliance for Social Responsibility /NASR/ is a national nongovernmental organization working actively for the creation and realization of effective national and local social policies, activities and services. The founders have made it their aim to unite the possibilities and stimulate the

\footnotetext{
16 National Report on Social Economy Sector in Bulgaria, www.southeast- europe.net/ document.cmt?id=191 (03.02.2015)

17 National Alliance for Social Responsibility, http://naso.bg/en/about-us/activities/mainobjectives (03.02.2015)
} 
efforts of NGOs, corporate subjects, municipalities and other entities to create a socially responsible environment, stimulating social engagements in the community network, helping the people in Bulgaria afford a better quality of life.

NASR realizes its activities through long-term aims in several directions:

- Support for persons with disabilities and other social groups mainly through the National Network of Social Service Providers, participation in the National Council for Integration of Persons with Disabilities and an active European partnership through the EASPD as its representative in Bulgaria.

- Formation and implementation of active local social policies, creation and development of social responsibility through the municipalities by increasing their opportunities and contribution to improving the social services, the quality of life of people in need and all citizens.

- Support for development of corporate social responsibility in Bulgaria and focusing on person centered approaches, especially those concerning people in need, including people with disabilities. Some of the biggest corporations in Bulgaria, which are members of NASR, for example Solvey Sodi AD, KCM 2000 AD, Aurubis Bulgaria AD and others, have made a strong contribution to reaching these aims.

- Spirituality, art and culture have an important role in the activities of NASR; they are a crucial condition for the success of any initiative and an integral part of the criteria for a better life.

Among their successful projects are: Pass It On - From Raising Awareness to Open Labour Market Opportunities for People with Disabilities through Vocational Training and Lifelong Strategies; The Common Voice Network Project - to build an international network for national lobby networks of social service providers for persons with intellectual, multiple disabilities and autism in the Central and Eastern European region; Empathy - an active social inclusion of people with disabilities through promotion and implementation of policies for equal opportunities and social inclusion by the creation of a Support Center for People with Disabilities.

\subsection{SOS Entrepreneurs}

SOS Entrepreneurs Foundation is a not-for-profit Bulgarian organisation, which offers supporting service for micro, small and medium-sized enterprises and for new entrepreneurs and start-ups in all phases of creation or consolidation of their project. Its mission is to promote and develop social entrepreneurship and private initiative in Bulgaria. SOS Entrepreneurs Foundation supports and accompanies entrepreneurs by providing information and 
consultancy. Its vision is to act as intermediary between companies seeking support and the supporting organization.

The main activities of the Foundation include:

- elaborating informational materials, databases, development of research, manuals, analyses and strategies;

- $\quad$ supporting civil society initiatives, projects, NGOs and entrepreneurs;

- organizing and participating in workshops, roundtables, conferences and thematic forums, seminars and workshops;

- establishing and developing networks of cooperation and participation in such networks, exchange of experiences, training and partnership initiatives;

- promoting case studies, "best practices" and innovative approaches among entrepreneurs in Bulgaria.

\subsection{Junior Achievement ${ }^{18}$}

Junior Achievement /JA/ is among the world's leading organization, offering contemporary programs and courses in business, economics, and entrepreneurial spirit development through educational and practical activities in economic and financial literacy, business skills, leadership, and success strategies. Since 1997 the organization motivates young people to be active and proactive and prepare them to know how to be able to realize their ideas in a competitive environment. JA Bulgaria realizes a number of initiatives with a special focus towards providing opportunities for personal development of disadvantaged young people:

- The Smart Start and Manager for a Day initiatives in 2012 featured the participation of 50 high school students of Roma ethnic origin from schools in Samokov, Sliven, Kotel, and Yambol. They all spent a busy working day at companies and institutions and learned how to write a CVs and motivation letters. Every year, young people from the SOS Kinderdorf network take part in the Manager for a Day initiative. Even without enjoying a special priority, they get selected by leading companies and institutions as one-day interns.

- JA Bulgaria gives opportunity to disadvantaged students (usually young people living in foster care) to be part of its summer internship program.

- In partnership with Coca Cola HBC Bulgaria, JA Bulgaria delivered a specialized one- week training in personal development, career management and entrepreneurship to students without parents living in the Foster Care Home in Doganovo village near Sofia.

$18 \quad$ Junior Achievement Bulgaria, www.jabulgaria.org(03.02.2015) 
- JA Bulgaria designed in 2014 partnership project on financial literacy with Metlife Bulgaria with an exclusive attention towards 4 schools in Sofia characterized by disadvantaged location in less developed neighborhoods, lower income of the families and poorer educational achievements. Financial literacy is especially crucial for young people with such background.

- JA Bulgaria "Social cohesion" project, funded by the U.S. Embassy, piloted a social innovation model for local community development and active participation of stakeholders through encouraging entrepreneurship education in grades 1-7 in schools in preselected economically and socially disadvantaged areas of the country. Two regions characterized with ethnically diverse population, low economic activity and high levels of unemployment benefited from the project - Shumen and Targovishte.

- JA Bulgaria project "Green Entrepreneurship for Sustainable Development" was specifically created with the idea to contribute to the creation of businesses that respect nature and embed a concern for nature at the very heart of their economic activity. JA Bulgaria's team took part in a tree-planting activity in 2014 (together with their partner company Traventuria) and their goal is to take part in at least one such activity every year.

\section{4. $A B L E^{19}$}

The Association of the Bulgarian Leaders and Entrepreneurs (ABLE) is a non-governmental organization, established by alumni of Bulgarian Young Leaders Program (BYLP). Their mission is to develop active civil society, inspire leadership and promote entrepreneurial culture in Bulgaria. ABLE is a vibrant community of entrepreneurial young people who try to make a difference in the Bulgarian reality.

ABLE engage in a variety of activities and projects among which different public events, competitions, incubator initiatives and others. The project ABLE Mentor aims to connect young professionals with high-school students and build a network of people, who are willing to share their experience, knowledge, personal challenges and aspirations. The project raises awareness among students about entrepreneurship as a means to overcome difficulties on the way to their goals. It makes information about career and academic development readily available. Finally, it helps students to dare make their first step to that long desired project. I- hub is another initiative of ABLE that aims to bridge the gap between the academic education and the design of marketable technological products. It is a two-month program that encourages cross-field

19 ABLE Bulgaria, http://ablebulgaria.org/en/ (03.02.2015) 
innovation and the cooperation between students and professionals with different backgrounds which is crucial for both their personal and professional advance. I-hub is also an opportunity for the best ideas to become reality. The program enables the participants to gain fundamental knowledge about how they can apply their ideas in the world of business through:

- $\quad$ short study of basic economics and business concepts;

- contest for market-oriented technological products developed in teams;

- exchange of knowledge and know-how with professionals in the field of business and innovation;

- constant feedback by mentors with experience;

- presentations before investors.

\subsection{The Unicredit Foundation}

Uni Credit Foundation was set up in 2003 as a corporate foundation of UniCredit and as testimony to the work done by the Group to promote a comprehensive set of values that form the basis of its corporate identity. Through corporate philanthropy, the Foundation intends to contribute to the growth of the community it works in, promoting the processes of social cohesion against a complex backdrop of inequality, need and transformation that characterizes modern society. With this objective, UniCredit Foundation undertakes to promote long-term initiatives, to seek innovation in different areas of social action and to construct effective, lasting partnerships with non-profit organizations.

The Foundation supports actions and players representing the social economy, which combine charity work with market principles to provide an ongoing response to the need for welfare services in the community, while simultaneously creating employment. The social objective may be sought through the direct provision of services in the field of welfare, education and training, healthcare, etc. or through the production of goods and services of any type, intended to create job opportunities for vulnerable individuals.

Uni Credit Foundation leverages the social enterprise model in its relationships with different non-profit players, relying on companies' natural predisposition to economic and financial sustainability and levels of efficiency usually required of them. It enables them to continuously produce and supply goods and services of social benefit, while simultaneously helping groups at serious risk of exclusion to find employment.

Another essential feature of the projects supported by UniCredit Foundation is innovative social research, combining the development of new means of interaction between the public sector, the private sector and the nonprofit sector to come up with sustainable solutions on emerging social issues. 


\section{Conclusion}

In order to encourage social entrepreneurship, it is necessary to ensure better awareness and promotion of the benefits and general impact of social enterprises to the economic and social development. The social and economic hardships during the last 20 years in Bulgarian can be overcome through the discovery and promotion of best practices and positive models as well as by spreading good examples of social entrepreneurship and social responsibility.

This aim of this paper was to provide a comprehensive literature review of the terms social responsibility and social entrepreneurship and to examine the current social entrepreneurship activities in Bulgaria. Several case studies were discussed to illustrate the successful implementation of particular entrepreneurial activities, which have successfully solved a number of social problems The analysis highlighted the importance of social entrepreneurial ideas for improving the business climate in the country. A major future challenge is the formulation of a sound legislative basis for social entrepreneurship as well as the development and implementation of governmental policy to support social entrepreneurs in their efforts.

\section{Acknowledgement}

This work was partially supported by the Project Grant BG051PO001-3.3.06-0053 of the European Social Fund and Bulgarian Ministry of Education and Science under the contract No. DO $01-4314 / 13.08 .13$.

\section{Literature}

- ABLE Bulgaria, http://ablebulgaria.org/en/ (03.02.2015)

- Communication from the Commission to the European Parliament, the Council, the European Economic and Social Committee of the Regions

- Dulevski, L. (2013): Analysis on "the social enterprise and social entrepreneurship", Republic of Bulgaria, Economic and Social Council, http:// www.esc.bg/ (03.02.2015)

- http://ec.europa.eu/internal_market/social_business/docs/COM2011_682_en.pdf (03.02.2015)

- Hockerts, K. (2006): "Entrepreneurial opportunity in social purpose business ventures". In J. Mair, J. Robinson, \& K. Hockerts (Eds.), Social entrepreneurship. Basingstoke, UK: Palgrave Macmillan.

- http://www.forbes.com/sites/iese/2015/01/28/4-things-we-can-learn-from-socialentrepreneurs/ (03.02.2015)

- Junior Achievement Bulgaria, www.jabulgaria.org (03.02.2015) 
- Kostetska, I., Berezyak, I. (2014), “Social Entrepreneurship as an Innovative Solution Mechanism of Social Problems of Society", Management Theory and Studies for Rural Business and Infrastructure Development, Vol. 36, No. 3.

- Lyons, T. S. (2013): “The Role of Social Entrepreneurship in Sustainable Business", http://www.triplepundit.com/, (http://www.triplepundit. com/2013/09/role-social- entrepreneurship-sustainable-business/) (03.02.2015)

- Martin, R. J. and Osberg, S. (2007): "Social entrepreneurship: The case for a definition", Stanford Social Innovation Review, Spring, 29-39.

- Masseti, B. L. (2008): "The social entrepreneurship matrix as a "tipping point" for economic change", E:CO, 10(3), 1-8.

- National Alliance for Social Responsibility, http://naso.bg/en/about-us/activities/main- objectives (03.02.2015)

- National Report on Social Economy Sector in Bulgaria, www.southeasteurope.net/document.cmt?id=191 (03.02.2015)

- Tracey, P., Phillips, N., and Jarvis, O. (2007): "Bridging institutional entrepreneurship and the creation of new organizational forms: A multilevel model", Organization Science.

- Vaccaro A. (2015): "4 Things We Can Learn From Social Entrepreneurs", Forbes.

- Yunus, M. (2008): Creating a World without Poverty: Social Business and the Future of Capitalism. New York: Public Affairs Books.

- Zahra, S. E., Gedajlovic, E., Neubaum, D. O., and Shulman, J. M. (2009): "A Typology of Social Entrepreneurs: Motives, Search Processes and Ethical Challenges", Journal of Business Venturing, 24(5), 519-532. 


\title{
Dr Danijela Ilijeva Koleva
}

Međunarodni fakultet Univerziteta u Šefildu / Univerzitet VUZF,

Sofija, Bugarska

Dr Julia Dobreva

Međunarodni fakultet Univerziteta u Šefildu / Univerzitet VUZF, Sofija, Bugarska

\section{DRUŠTVENO PREDUZETNIŠTVO KAO OBLIK DRUŠTVENE ODGOVORNOSTI U BUGARSKOJ}

\begin{abstract}
S a ž e t a k
Društveno preduzetništvo postaje sve popularniji oblik društvene odgovornosti i način da se reše mnogobrojni gorući socijalni problemi. Da bi neka zajednica podstakla društveno preduzetništvo, potrebno joj je okruženje u kojem takve ideje mogu da nastanu i razviju se u živu poslovnu aktivnost. Ovaj rad ima za cilj da pruži sveobuhvatan pregled literature o pojmovima društvene odgovornosti i društvenog preduzetništva i da ispita postojeće aktivnosti društvenog preduzetništva u Bugarskoj. Analiza rasvetljava značaj ideja društvene odgovornosti za poboljšanje poslovne klime u zemlji. Razmotreno je nekoliko studija slučaja, da bi bili pruženi konkretni dokazi o specifičnim preduzetničkim aktivnostima, zahvaljujući kojima je uspešno rešeno nekoliko socijalnih problema.

Ključne reči: korporativna društvena odgovornost, socijalno preduzetništvo, socijalna odgovornost
\end{abstract}

